\title{
Correlation of Serum Anti-Clq Antibody Levels and Disease Activity in Patients with Systemic Lupus Erythematosus
}

\section{Ferdy Ferdian"1, Riardi Pramudiyo², Laniyati Hamijoyo ${ }^{3}$}

${ }^{1}$ Departement of Internal Medicine, Faculty of Medicine, University of Padjajaran, Hasan Sadikin Hospital

${ }^{2}$ Rheumatology Division, Departement of Internal Medicine, Faculty of Medicine, University of Padjajaran, Hasan Sadikin Hospital

${ }^{3}$ Rheumatology Division, Departement of Internal Medicine, Faculty of Medicine, University of Padjajaran, Hasan Sadikin Hospital

\author{
A R T I C L E I N F O \\ Keywords: \\ Anti-C1q antibody \\ SLE \\ SELENA-SLEDAI.

\section{Corresponding author: \\ Ferdy Ferdian \\ E-mail address: polluxchiron@gmail.com}

All authors have reviewed and approved the final version of the manuscript.

https://doi.org/10.37275/IJR.v10i1.1

\begin{abstract}
A B S T R A C T
Background. Antibody to complement C1q (Anti-C1q Antibody) can be found in Systemic Lupus Erythematosus (SLE) patients. Complement C1q plays a role in the clearance of apoptotic cells and immune complexes. Anti-C1q causes complement C1q become inactive so that the clearance decreases, which induces self antigen and inflammatory response. Many tissue inflammation are associated with disease activity and lupus manifestations. The aim of this study is to find out the correlation of antiC1q level with disease activity, so that anti-C1q can be used as an objective indicator of inflammation along with SELENA-SLEDAI. Method. This is an analytic descriptive study with cross sectional design. Anti-C1q antibody levels were measured in 52 SLE patients who are hospitalized or treated routinely in outpatient clinic of Rheumatology Dr.Hasan Sadikin Hospital Bandung Indonesia from October to December 2015. Result. Most of the study subjects were women (94\%), with a median age of 33 years. There were 13 new patients $(25 \%)$, and the rest 42 patients were treated routinely. The median SELENA-SLEDAI was 6 (0-32). Subject were divided into no activity $(11.5 \%)$, low disease activity (34.6\%), medium disease activity $(25 \%)$ high disease activity $(15.4 \%)$ and very high disease activity (13.5\%). Median anti-C1q level was 3.92 $\mathrm{U} / \mathrm{mL}$ (range 0.6-100.2 U/mL). Anti-C1q antibody levels were positively correlated with SLE disease activity based on SELENA-SLEDAI scores ( $\mathrm{r}= \pm 0.304$; $\mathrm{p}=0.014)$.Conclusion. Anti-C1q antibody levels has mild correlated with lupus disease activity based on SELENA-SLEDAI score
\end{abstract}

\section{Introduction}

Systemic lupus erythematosus (SLE) is a prototypic systemic autoimmune disease characterized by heterogeneous multisystem involvement. Clinical features, course of disease and the prognosis can be quite variable. ${ }^{1}$ Lupus primarily affects women of childbearing years. ${ }^{2}$ Many research highlight the increased mortality rate in SLE patients compared with the general population. ${ }^{3,4}$ Immune system in SLE patient characterized by lymphocytes $B$ cell hyperactivity and autoantibody production. ${ }^{1}$ One of the pathogenesis of SLE is a disorder of the clearance of apoptotic cells.1,4 The complement system plays a significant role in facilitating the clearance of apoptotic cells and immune complexes and prevent the accumulation of immune complex organ systems. 1,5,6,7 Complement $\mathrm{C} 1 \mathrm{q}$ is a component of the initiation of the classical pathway (what kind of the pathway?) and plays an important role in the complement system as a whole. ${ }^{8}$

Antibodies to complement C1q (Anti-Clq Antibody) can be found in patients with SLE due to chronic activation of the complement system. ${ }^{9}$ Anti-C1q antibody disrupts the clearance of immune complexes and cell apoptosis. Immune complexes becomes bulky and not easily soluble, The immune complex will be the source of inflammation amplification (disease activity). 
Prolonged inflammation would cause irreversible tissue damage (disease damage). ${ }^{1}$

Disease activity which very fluctuated in lupus patients requires objective monitoring clinical parameters. ${ }^{1}$ Castrejon et al. reported that a parameter that is widely used in the world and is recommended for use in future studies is the Safety of Estrogens in Lupus Erythematosus National Assessment Systemic Lupus Erythematosus Disease Activity Index (SELENASLEDAI) and SLEDAI-2K. ${ }^{10}$

Studies of anti-C1q antibodies in various countries, found variation in research results. Some studies found a link between levels of anti-C1q antibodies with disease activity, 11-16 while other studies do not found the relationship.17-19 One of the causes of such diversity is, there is a difference between research race with one another. This study is the first in Dr. Hasan Sadikin Hospital Bandung Indonesia and all of the subjects are Asiatic race. The results of this study is expected to add the role of anti-C1q antibodies in patients with lupus.

The aims of this study is to determine the correlation of anti-C1q antibody levels with disease activity score based on the SELENA-SLEDAI in patients with SLE.

\section{Research Methods}

This research is descriptive analytic and a crosssectional design. Targeted population are SLE patients who are diagnosed based on revised criteria of SLE from American College of Rheumatology (ACR). Sampling was performed consecutively within a certain time, fulfil=fufill? the minimum sample of 52 to the power of study. The inclusion criteria of research are women and men aged over 14 years (not over 18 years?) who were diagnosed SLE, outpatients and inpatients, and had signed informed consent. Exclusion criteria included pregnant patients, suffered from hepatitis $\mathrm{B}$ or $\mathrm{C}$, patients with severe medical conditions or psychiatric disorder that causes uncooperative.

All the subjects who were eligible were evaluated using SELENA-SLEDAI score, then were performed venous blood sampling, included routine hematology test, anti-C1q antibody level, levels of complement C3 and levels of anti-dsDNA and urine test. Anti-C1q levels were measured using micro ELISA.

Characteristics of research subjects are presented in tabular form (table no.) correlation between anti-C1q antibodies level with lupus disease activity was calculated by Spearman Correlation Test. Data were analyzed using wessa program.(?) All statistical tests were considered significant if $\mathrm{p}$ value $<0.05$. Ethical clearance was obtained from the Research Ethics Committee Medical Faculty Universitas Padjajaran Bandung Indonesia.

\section{Results}

The study sampling was conducted from October to December 2015 and obtained 52 subjects.

Table 1 shows the baseline characteristics of subjects. Most of the subjects were woman (94\%), with an mean age at $33 \pm 10$ years(please use the usual word). Most of the subjects were outpatient. Disease activity based on the SELENA-SLEDAI score had a median of 6 . The therapy(better use treatment) most widely used by subjects is methylprednisolone (100\%). Other therapy(better use treatment) were chloroquine, azathioprine, cyclosporine, cyclophosphamide and methotrexate.

The most dominant history of organ involvement was mucocutaneous involvement as much as $84.6 \%$, $78.8 \%$ musculoskeletal and 53.8\% renal involvement. The Most organ involvement at the time of research is (was) 42.3\% renal involvement, 19.2\% mucocutaneous and $15.4 \%$ musculoskeletal. (Figure 1)

This study showed a mild correlation between AntiC1q antibody levels and SLE disease activity based on SELENA-SLEDAI score. (Figure 2)

Table 2. showed that median of anti-C1q antibody in the group of SLE with renal involvement (10.05 U / $\mathrm{mL}$ ) was higher than the group of SLE without renal involvement (3.49 $\mathrm{U} / \mathrm{mL}$ ) and the difference was statistically significant $(\mathrm{p}<0.05)$, while mucocutaneous involvement, musculoskeletal involvement, haematological involvement and NPSLE are not statistically significant. 
Table 1. Characteristics of Subjects $(n=52)$

\begin{tabular}{|c|c|}
\hline Variable & Total \\
\hline \multicolumn{2}{|l|}{$\operatorname{Sex}(n, \%)$} \\
\hline - Male & $3(5.8)$ \\
\hline - Female & $49(94.2)$ \\
\hline Age at the time of research (me & $33 \pm 10$ \\
\hline Age at diagnosed (mean years) & $29+9$ \\
\hline SLE duration (years) & $4(0-13)$ \\
\hline \multicolumn{2}{|l|}{ Types of Treatment (n, \%) } \\
\hline - Outpatients & $42(80.8)$ \\
\hline - Inpatients & $10(19.2)$ \\
\hline SELENA SLEDAI & $6(0-32)$ \\
\hline - Without activity (Score 0) & $6(11.5)$ \\
\hline - Mild activity (Score 1-5) & $18(34.6)$ \\
\hline - Moderate activity (6-10) & $13(25)$ \\
\hline - High activity (11-19) & $8(15.4)$ \\
\hline - Very high activity (>20) & 7 (13.5) \\
\hline \multicolumn{2}{|l|}{ Laboratorium } \\
\hline - Hemoglobin (g/dL) & $11.3 \pm 2.1$ \\
\hline - Leukosit (/mm3) & $6888+3487$ \\
\hline - Platelet (/mm3) & $247 . \overline{000}+91375$ \\
\hline$-\mathrm{C} 3(\mathrm{mg} / \mathrm{dL})$ & $93+44$ \\
\hline - Anti-dsDNA (IU/mL) & $21 \overline{4}(11-1758)$ \\
\hline \multicolumn{2}{|l|}{ Medication (n, \%) } \\
\hline - methylprednisolone & $52(100)$ \\
\hline - chloroquine & $23(44)$ \\
\hline - azathioprine & $10(19)$ \\
\hline - cyclosporine & $1(2)$ \\
\hline - cyclophosphamide & $6(11)$ \\
\hline - Methorexate & $2(4)$ \\
\hline - Mycophenolate mofetil & $0(0)$ \\
\hline
\end{tabular}

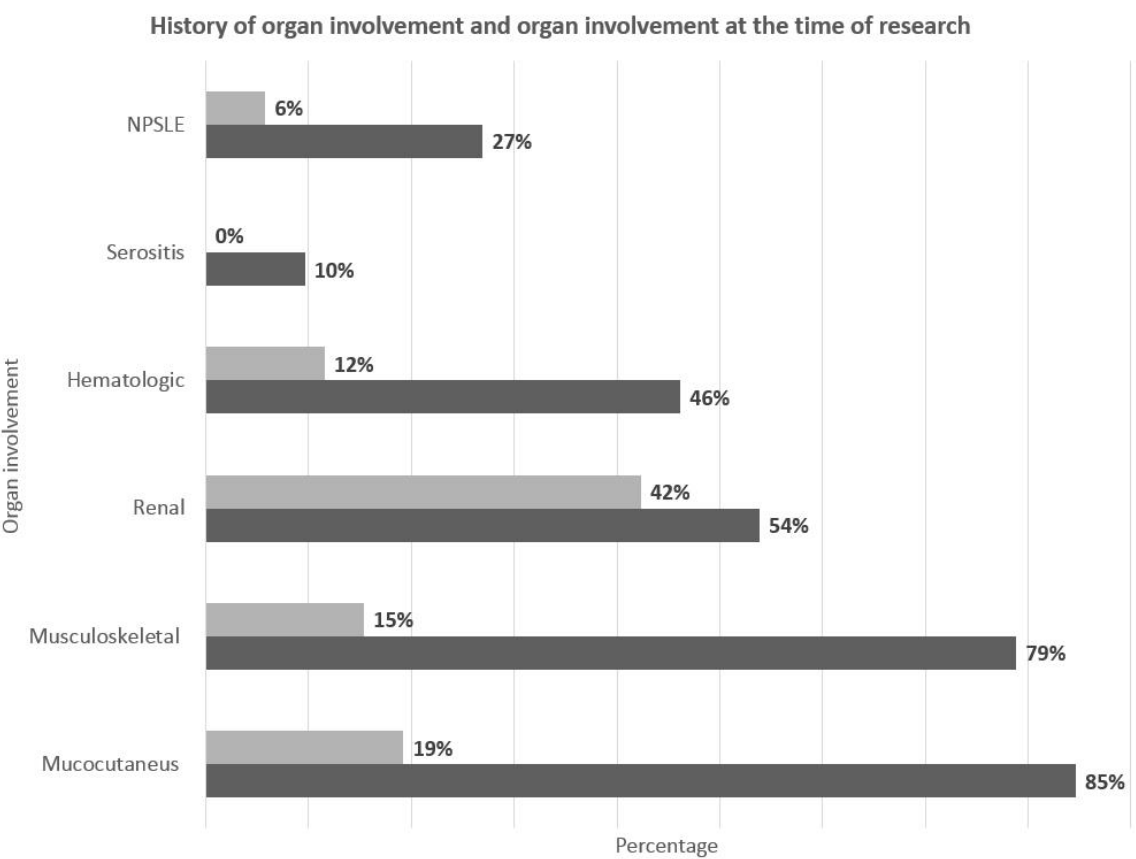

Figure 1. History of organ involvement from 52 consecutive patients with active systemic lupus erythematosus (SLE) was mucocutaneous involvement as much as $84.6 \%, 78.8 \%$ musculoskeletal and $53.8 \%$ renal involvement. Organ involvement at the time of research is $42.3 \%$ renal involvement, $19.2 \%$ mucocutaneous and $15.4 \%$ musculoskeletal 


\section{Correlations between anti-C1q antibody titers and the \\ SELENA-SLEDAI score}

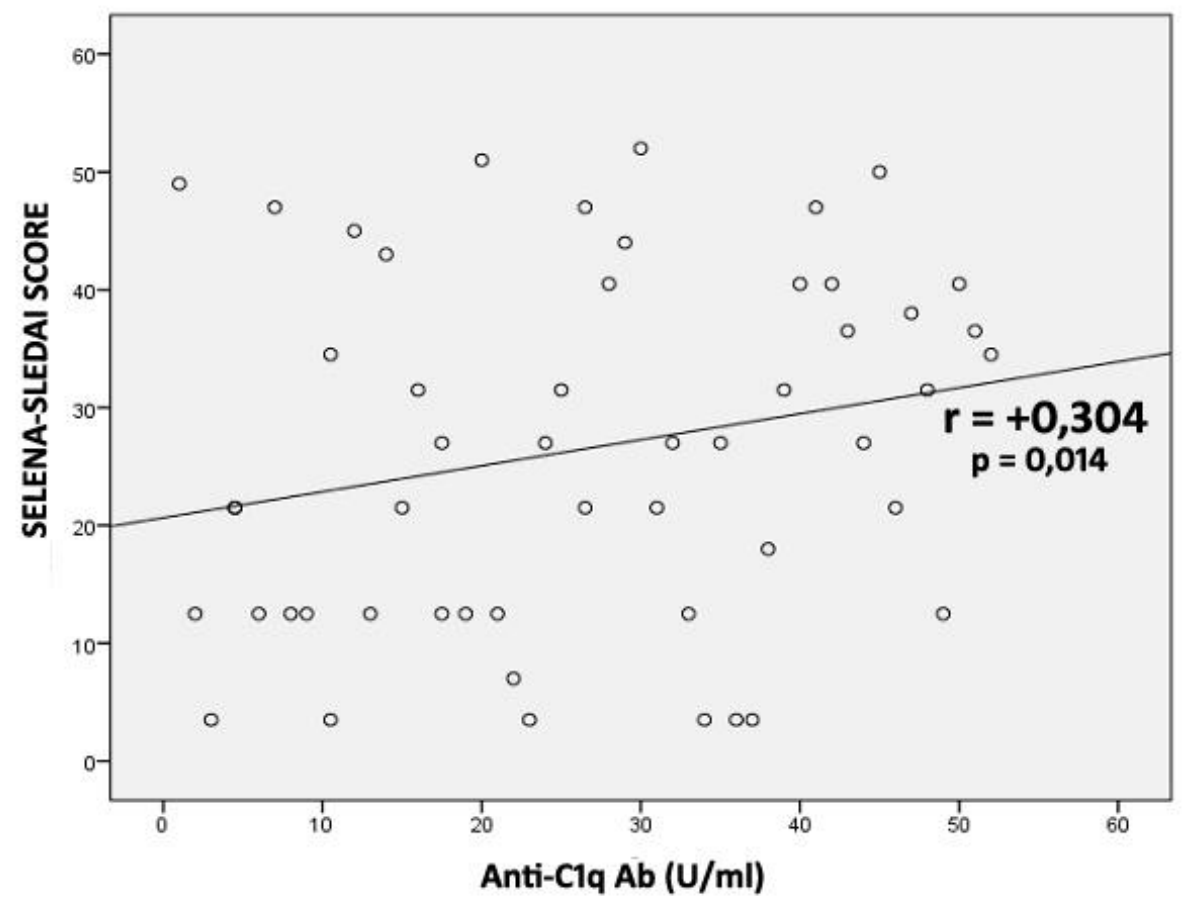

Figure 2. Correlations between anti-C1q antibody titers and SELENA-SLEDAI score, as measured in 52 consecutive patient with active SLE. For comparison, significant positive correlation $(p=0.014)$ were observed.

Table 2. Differences in levels of anti-C1q antibodies in various organ involvement

\begin{tabular}{|c|c|c|c|c|}
\hline & & \multirow[t]{2}{*}{$\mathrm{n}$} & \multicolumn{2}{|c|}{$\begin{array}{c}\text { Antibodi anti-C1q } \\
\text { levels }\end{array}$} \\
\hline & & & Median & P value \\
\hline \multicolumn{5}{|c|}{ Mucocutaneus } \\
\hline . & Yes & 10 & 3,83 & 0,736 \\
\hline & No & 42 & 3,92 & \\
\hline \multicolumn{5}{|c|}{ Musculoskeletal } \\
\hline & Yes & 8 & 3,63 & 0,525 \\
\hline & No & 44 & 3,93 & \\
\hline \multicolumn{5}{|c|}{ Renal } \\
\hline & Yes & 22 & 10,05 & $0,004 *$ \\
\hline & No & 30 & 3,49 & \\
\hline \multicolumn{5}{|c|}{ Hematologic } \\
\hline - & Yes & 6 & 3,84 & 0,376 \\
\hline - & No & 46 & 3,92 & \\
\hline \multicolumn{5}{|c|}{ NPSLE } \\
\hline - & Yes & 3 & 3.5 & 0,384 \\
\hline- & No & 49 & 3,92 & \\
\hline
\end{tabular}




\section{DISCUSSION}

This study found a (mild) positive correlation between levels of anti-C1q antibodies with lupus disease activity based on the SELENA-SLEDAI score $(\mathrm{r}= \pm 0.304, \mathrm{p}<0.05)$. Previous studies have shown that anti-C1q antibody levels in lupus patients correlates with disease activity, the strength of the correlation is varies from mild to strong correlation. Siegert et al. conducted cohort research for three years follow up and found serum anti-C1q were significantly but weak correlated with the SLEDAI score $(\mathrm{r}= \pm 0,18 ; \mathrm{p}<0.01)^{20}$, in contrast with research conducted by Cai et al. in China, found a strong correlation between the levels of anti-C1q antibodies with disease activity with SLEDAI score $(\mathrm{r}=\neq 0.792, \mathrm{p}<0.001) .{ }^{21}$ Katsumata et al. in Japan, concluded that the anti-C1q antibody levels were correlated with SLEDAI score $2 \mathrm{~K}(\mathrm{r}= \pm 0.34$, $\mathrm{p}<0.0001) .{ }^{16}$ Mahayadin et al. in Malaysia conducted a crosssectional study in 2014 with 95 patients with SLE, in which the research subjects are dominated by the Malays (95\%). That study concluded that a strong correlation between the levels of anti-C1q antibodies with disease activity with SLEDAI scoring system $(\mathrm{r}= \pm 0.559, \mathrm{p}<0.001) .22$

This study found serum anti-C1q differences between subjects with renal involvement and without renal involvement, whereas the involvement of mucocutaneous, musculoskeletal, hematologic and NPSLE are no statistically significant differences. It is also stated by Siegert et al. who comparing the levels of anti-C1q at various organ involvement, found differences in levels of anti-C1q patients with renal involvement but no difference in other organ involvement. 20 Mok et al. measuring the levels of autoantibodies in patients with SLE, it was concluded that the anti-C1q antibodies specific for kidney involvement when compared with other antibodies. ${ }^{14}$ Akhter et al. stated that anti-C1q antibodies are superior when compared to (the) other markers such as anti-dsDNA to detect the presence of renal flares. ${ }^{13}$

Differences in correlation (of the) anti-C1q antibody levels against global lupus disease activity or a variety of organ involvement in the various countries, likely due to their genetic diversity and differences in research methodology. The literature explains that the pathogenesis of SLE is closely related to genetic factors. In recent years Genome wide association study (GWAS) shows that there are more than a hundred genes involved in the pathogenesis of SLE, and each of these genes have effects that are moderate. Additional evidence shows that there are differences in the genes involved in a particular ethnic. For example, the gene that regulates FC Gamma Reseptor (FCGR) has long been associated with the pathogenesis of SLE in Asia. Until now FCGR2A, FCGR2B and FCGR3A polymorphism has been associated with SLE in Asia. 23 Early research on the matter reported by Salmon et al. was found that differences in FCGR3A allele involved in the pathogenesis of SLE in Korea. ${ }^{24}$, (which) associated with anti-C1q antibodies, Orbai et al. stated that antiC1q antibody (was?) more common in Asian ethnic (40.5\%) compared with Caucasian ethnic (27.6\%) and African (21.7\%) although the difference was not significant. 25 Pradhan et al. in India mentioned that the secretion of anti-C1q antibodies were related to genetic polymorphisms of FCGR2A receptors. There are two alleles that encode FCGR2A ie H131 and R131. FC Gamma 2A receptor with $\mathrm{H} 131$ allele have a good affinity towards IgG2, while FC Gamma 2A receptor with R131 allele have a weak affinity towards IgG2. Pradhan et al. found that patients with anti-C1q antibody positive, $71 \%$ had R131/H131 genotype, $22.6 \%$ had R131/R131 genotype and 6.4\% had H131/H131 genotype.26 In this study, the research subject is dominated by ethnic Sundanese, where, according to Kroeber AL, Sundanese belong to the Mongoloid Malayan similar ethnic Malays in a study conducted by Mahayadin et al. in Malaysia.22, Malayan Mongoloid ethnic still allied with the Asiatic Mongoloid such as Chinese and Japanese. 27 This may explain why the correlation of research in Europe is different from research in Asia, ethnic differences are significant, as previously described, while the difference in strength of the correlation between ethnic Asiatics, such as in Malaysia, China, Japan and Indonesia needs to do further research as has been done by Pradhan et al. 
Limitation of this study is, the age of the study subjects was not uniform and as much as $75 \%$ of patients are outpatients where the study subjects have received immunosuppressive therapy. Some studies reports that anti-C1q antibody levels decreased after the administration of immunosuppressive drugs. Immunosuppressive drugs have a suppressive effect on $T$ cells and B cells. This suppression causes a decrease in the immune response and decreased production of autoantibodies in patients with SLE, including decreased production of anti-C1q autoantibodies. Beside that, the method of this study was crosssectional so that the strength of the relationship of variables to be lower when compared to a cohort study.

\section{CONCLUSION}

The results of this study shows a mild positive correlation and statistically significant between antiC1q antibodies levels with disease activity in patients with lupus based on the SELENA SLEDAI score.

\section{Acknowledgement}

No conflic of interest

\section{REFERENCES}

1. Wallace DJ, Hahn BH, editor. Dubois Lupus Erythematosus, 8th ed. Los Angeles: Elsevier; 2013

2. Danchenko N, Satia JA, Anthony MS. Epidemiology of systemic lupus erythematosus: a comparison of worldwide disease burden. Lupus. 2006;15(5):30818

3. Cervera R, Khamashta MA, Font J, Sebastiani GD, Gil A, Lavilla $\mathrm{P}$, et al. Morbidity and mortality in systemic lupus erythematosus during a 10-year period, a comparison of early and late manifestation in a cohort of 1000 patients. Medicine 2003;82:299308.

4. Bernatsky S, Boivin JF, Joseph L, Manzi S, Ginzler E, Gladman D. Mortality in Systemic Lupus Erythematosus. Arthritis \& Rheumatism vol 54, no. 8, 2006

5. Tsokos GC, Gordon C, Smolen JS, editor. Systemic lupus erythematosus. Edisi ke-1. Philadelphia: Elsevier; 2007

6. Hollers VM, 2004, Anti-C1q autoantibodies amplify pathogenic complement activation in systemic lupus erythematosus, J. Clin. Invest. 114:616-19

7. Sontheimer RD, Racila E, Racila DM. C1q: Its
Functions within the Innate and Adaptive Immune Responses and its Role in Lupus Autoimmunity. J Invest Dermatol. 2005;125:14-23

8. Bacchi VF, Noel LH, Schifferli JA. No lupus nephritis in the absence of antiC1q autoantibodies? Nephrol Dial Transplant (2002) 17: 2041-43.

9. Eggleton P, Ukkoumune OC, Cottrel I, Khan A, Moqsood S, Thorner J et al. Autoantibodies against C1q as a Diagnostic Measure of Lupus Nephritis: Systematic Review and Meta-analysis. J Clin Cell Immunol. ; 5(2) 2-9.

10.Castrejon I, Tani C, Jolly M, Huang A, Mosca M. Assessment of Disease Activity in Systemic Lupus Erythematosus. Clin Exp Rheumatol 2014; 32 (Suppl. 85): S85-95.

11.Oelzner P, Deliyska B, Funfstuck R, Hein G, Hermmann D, Stein G. Anti-C1q antibodies and antiendothelial cell antibodies in systemic lupus erythematosus - relationship with disease activity and renal involvement. Clinical Rheumatology, 2003, Vol 22, Issue 4-5, pp 271-8.

12. Sinico RA, Radice A, Ikehata M, Giammarresi G, Corace C, et al. Anti-C1q autoantibodies in lupus nephritis: prevalence and clinical significance. Ann N Y Acad Sci. 2005; 1050:193-200.

13.Akhter E, Burlingame RW, Seaman A, Magder L, Petri M. Anti-C1q antibodies have higher correlation with flares of lupus nephritis than other serum markers. Lupus. 2011;20:1267-74.

14. Mok CC, Ho LY, Leung HW, Wong LG. Performance of anti-C1q, antinucleosome, and anti-dsDNA antibodies for detecting concurrent disease activity of systemic lupus erythematosus. Transl Res. 2010 Dec;156(6):320-5.

15.Kumar A, Gupta R, Varghese T, Pande RM, Singal VK, Garg OP. Anti-C1q antibody as a marker of disease activity in systemic lupus erythematosus. Indian J Med Res. 1999 Dec;110:190-3.

16.Katsumata Y, Miyake K, Kawaguchi Y, Okamoto Y, Kawamoto M, Gono T, et al. Anti-C1q antibodies are associated with systemic lupus erythematosus global activity but not specifically with nephritis: a controlled study of 126 consecutive patients. Arthritis Rheum. 2011; 63:2436-44.

17.Jesus AA, Campos LM, Liphaus BL, CarneiroSampaio M, Mangueira CL, et al. Anti-C1q, antichromatin/nucleosome, and anti-dsDNA antibodies in juvenile systemic lupus erythematosus patients. Rev Bras Reumatol. 2012; 52:976-81.

18.Altintas ND, Tiryaki AO, Tutkak H, Duzgun N. An analysis of the relationship between different autoantibodies and clinical findings in a group of Turkish patients with Systemic Lupus Erythematosus. Gazi Medical Journal. 2008: Cilt 19: Say1 3: 126-32.

19.Trad B, Hassine B, Khalifa M, Idriss N, Slama F, 
Bahri $\mathrm{F}$ et al. Anti-C1q antibodies and systemic lupus erythematosus in the Tunisian population. Pathol Biol (Paris). 2013 Jun;61(3):113-6.

20. Siegert CE, Daha MR, Tseng CM, Coremans IE, Van LA, Breedveld FC. Predictive value of IgG autoantibodies against $\mathrm{C} 1 \mathrm{q}$ for nephritis in systemic lupus erythematosus. Ann Rheum Dis 1993; 52: 851-6.

21.Cai X, Yang X, Lian F, Lin X, Liang M, Li J, et al. Correlation between serum anti-C1q antibody levels and renal pathological characteristics and prognostic significance of anti-C1q antibody in lupus nephritis. J Rheumatol. 2010;37:759-65.

22. Mahayidin H, Yahya NK, Ghazali WS, Ismail AM, Hamid WZ. The Usefulness of Endothelial Cell Adhesion Molecules and Anti-C1q Antibody in Monitoring Systemic Lupus Erythematosus Disease Activity. International Scholarly Research Notices Vol 2014, Article ID 275194.
23.Yuan YJ, Luo XB, Shen N. Current advances in lupus genetic and genomic studies in Asia. Lupus (2010) 19, 1374-1383

24.Salmon JE, Ng S, Yoo DH, Kim TH, Kim SY, Song GG. Altered distribution of Fcgamma receptor IIIA alleles in a cohort of Korean patients with lupus nephritis. Arthritis Rheum 1999; 42: 818-819.

25. Orbai AM, Trueddson L, Sturfelt G, Nived O, Fang $\mathrm{H}$, Alarcon GS, et al. Anti-C1q antibodies in systemic lupus erythematosus. Lupus (2015) 24, 42-9.

26.Pradhan V, Patwardhan M, Nadkarni A, Ghosh K. Fc $\gamma$ RIIA Genotypes and Its Association with AntiC1q Autoantibodies in Lupus Nephritis (LN) Patients from Western India. Autoimmune Diseases Vol 2010, Article ID 470695

27.Kroeber AL. Anthropology: race, language, culture, psychology, pre-history. New York : Harcourt, Brace. 1948. h. 851-6. 